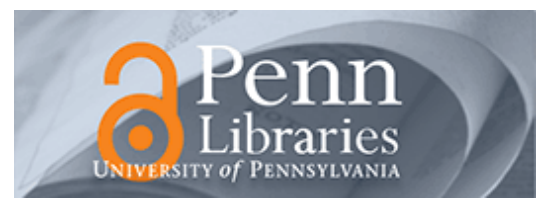

University of Pennsylvania

ScholarlyCommons

Operations, Information and Decisions Papers

Wharton Faculty Research

$1-1998$

\title{
When Product Development Performance Makes a Difference: A Statistical Analysis in the Electronics Industry
}

Christian Terwiesch

University of Pennsylvania

Christoph H. Loch

Follow this and additional works at: https://repository.upenn.edu/oid_papers

Part of the Other Business Commons, Other Electrical and Computer Engineering Commons, and the Statistical Methodology Commons

\section{Recommended Citation}

Terwiesch, C., \& Loch, C. H. (1998). When Product Development Performance Makes a Difference: A Statistical Analysis in the Electronics Industry. The Journal of Product Innovation Management, 15 (1), 3-15. http://dx.doi.org/10.1111/1540-5885.1510003

This paper is posted at ScholarlyCommons. https://repository.upenn.edu/oid_papers/32

For more information, please contact repository@pobox.upenn.edu. 


\title{
When Product Development Performance Makes a Difference: A Statistical Analysis in the Electronics Industry
}

\author{
Abstract \\ Throughout the pages of JPIM and other publications, researchers and practitioners devote considerable \\ effort to identifying the dimensions of new-product development (NPD) performance that relate most \\ closely to business success. Although we may hope to unveil a set of universal truths about the \\ relationship between NPD performance and business success, the relevant NPD performance measures \\ appear to depend on the industry in which a firm competes. \\ In fact, Christian Terwiesch, Christoph Loch, and Martin Niederkofler suggest that the overall relevance of \\ NPD performance to business success depends on the firm's competitive market environment. In a study \\ of 86 business units operating in 12 different electronics industries worldwide, they develop a market \\ contingency framework for understanding the impact of NPD performance on a firm's profitability. Their \\ study uses data from the "Excellence in Electronics" project, a joint research effort by Stanford University, \\ the University of Augsburg, and McKinsey \& Co. \\ They describe market context in terms of three dimensions: market share, market growth, and external \\ stability-that is, the average product life cycle duration in the market. Looking at all 86 business units in \\ the study, they find that industry membership accounts for $23 \%$ of the variance in profits, with 18 percent \\ of the variance determined by industry profitability and $5 \%$ by the three dimensions of market context. For \\ the firms in the study, development performance has the most significant effect in slow-growth markets \\ and in markets with long product life cycles. In these stable industries, low development intensity, product \\ line freshness, and technical product performance increase profitability. \\ The results indicate that NPD performance plays a much more important role for explaining the \\ profitability of dominant firms than that of the low-market-share firms in the study. NPD performance \\ explains $30 \%$ of the profitability variance among the high-market-share business units in the study, but \\ none of the variance for the low-market-share business units. Although the profitability of the smaller \\ firms in the study is driven primarily by the industry environment, these firms can compete on the basis of \\ superior technical performance. \\ Disciplines \\ Other Business | Other Electrical and Computer Engineering | Statistical Methodology
}




\title{
WHEN PROdUCT DEVELOPMENT PERFoRMANCE MAKES A DIFfERENCE: A STATISTICAL ANALYSIS IN THE ELECTRONICS INDUSTRY
}

\author{
by \\ C. TERWIESCH* \\ C. LOCH** \\ and \\ M. NIEDERKOFLER $\dagger$ \\ 96/78/TM \\ (Revised version of 96/29/TM)
}

* PhD Candidate, at INSEAD, Boulevard de Constance, Fontainebleau 77305 Cedex, France.

** $\quad$ Assistant Professor of Operations Management, at INSEAD, Boulevard de Constance, Fontainebleau 77305 Cedex, France.

$\dagger \quad$ McKinsey \& Company.

A working paper in the INSEAD Working Paper Series is intended as a means whereby a faculty researcher's thoughts and findings may be communicated to interested readers. The paper should be considered preliminary in nature and may require revision.

Printed at INSEAD, Fontainebleau, France. 


\title{
When Product Development Performance Makes a Difference: A Statistical Analysis in the Electronics Industry
}

Christian Terwiesch*

INSEAD
Christoph Loch

INSEAD
Martin Niederkofler

McKinsey \& Company

Revised, November 1996

\begin{abstract}
High performance of the product development function is seen as a path to competitive advantage in many industries. Product development performance is commonly measured as the efficient and rapid development of new and high performing products. However, the relevance of development performance for business success depends on the competitive market environment in which a firm operates. This article develops a market contingency framework of the impact of development performance on profitability. The market environment dimensions are growth, industry profitability, market share and product life cycles. We statistically test the framework on data from 86 companies in 12 electronics industries worldwide. We show that product development performance is more important in technologically stable and low growth industries. In addition, large companies can significantly impact their financial performance through product development, whereas the profitability of small firms is driven mainly by their industry environment.
\end{abstract}

\footnotetext{
- The authors thank the editor and two anonymous referees for many comments that helped to substantially improve this article.
} 
The CEO of a worldwide leading car mamfacturer, after being asked for his technical vision for the next decade: "Money, Money, and again Money."

\section{INTRODUCTION}

New product development (NPD) has received much attention in academic and managerial literature over the last ten years because it is seen as an important source of competitive advantage (see, e.g., $[2,3,40]$ ). An important part of the NPD literature is dedicated to identifying NPD performance dimensions that drive the business success of a company. Traditionally, such dimensions have been examined at the project level [6, $7,8]$ and have only recently been extended to the product development function as a whole $[1,9,12,20]$.

Commonly used NPD performance dimensions can be grouped under development time, cost and quality. They include the length of development cycles and the fraction of products first to market, development productivity, the percentage of distinctive and financially successful new products, or the proportion of sales from new products [15, 40]. Some empirical studies of NPD performance stretch across industries [6], while others are industry specific $[7,8]$ : Both groups of studies typically share the implicit assumption that performance dimensions can be generalized to different market environments. Recent work, however, has challenged this assumption and suggests that the relevant NPD performance dimensions change across industries $[3,21]$.

The present article demonstrates the importance of the market environment in the assessment of NPD performance. Our study is based on 86 business units across 12 different electronics industries worldwide. We develop a market contingency framework of the NPD performance impact on business success. We show that NPD performance is important in technologically stable and mature industries, but we find no significant link between development performance and profitability in industries with fast growth or short product life cycles. In addition, large companies can significantly impact their financial performance through product development, whereas the profitability of small firms is driven mainly by their industry environment. 


\section{LTERATURE REVIEW}

The Product Development Performance Literature

The recognition that the NPD performance impact on business success depends on the market environment is recent in the NPD performance literature. Traditionally, studies have been targeted at two levels of analysis. First, there are many studies on NPD performance focused on the individual project level. These studies have managed to find and confirm a number of key project success drivers, such as understanding user needs, internal and external communication, attention to marketing, efficiency of development, and the authority of R\&D managers (see, e.g., $[25,31,32]$ ). In addition, the importance of market pull (listening to the customer's voice), as opposed to technology push, was discovered. These research findings were later complemented and confirmed by, among others, Zirger \& Maidique (1990) [41] and Cooper et al. [6 - 8]. Cooper and Kleinschmidt [7], for example, identify five key predictors of project success, namely customer orientation, sharp product definition, a cross-functional development team, synergy with existing products (market strength), and an efficient development process. Most of the project-oriented studies are industry specific, and it has been pointed out that most of them apply to stable and mature industries (e.g., $[3,7,8])$.

Second, there are technology strategy studies at the aggregate industry level - for example, the literature on technology life cycles and their influences on competition (e.g., Tushman and Rosenkopf (1992) [37], or Utterback and Suárez (1993) [38]). Adler (1989) points out that our understanding of $R \& D$ as a success driver at the firm level remains weak: "The polarization of research at these two levels [project and industry] leaves a gap at the firm level, limiting the value of research results for strategy analysis" (p. 27 [1], note by the authors).

Recently, this "gap" has been addressed by an increasing interest in NPD performance measurement at the level of the firm $[9,13,15]$. These articles offer overall NPD performance measures, but do not test their relevant impact on business success. 
Two studies are close to the focus of the present article. Morbey (1988) [24] finds that R\&D expense levels (gained from annual reports) predict growth, but not profitability. Morbey's study looks across many industries but does not take into account NPD performance (only R\&D expense), nor does it look at characteristics of the market environment. Firth and Narayanan (1996) [12] observe that for large market-dominant firms, "market-newness" (that is, product newness relative to the existing market offering) is the development performance variable with the highest benefit for retums.

\section{The Importance of Market Context: Insights From Other Fields}

Strategy research has emphasized the influence of environmental variables for a long time [14, 29]. Miller and Friesen (1981) and Miller (1987) $[22,23]$ argue that in uncertain environments, the fate of small- and medium-sized firms is determined by industry characteristics, such as technology change or market growth. Large firms, in contrast, are less driven by such contextual influences, due to their market power, resources, and external stability [22].

Porter [27, 28] presents a strategic framework to explain how the importance of product development might change over time, with the changing industry context. This framework is based on the product life cycle model. The product life cycle comprises four stages: embryonic, growth, mature, and decline. The product life cycle model predicts that marketing is more important than development in phases of high industry growth because market awareness and volume building are the key challenges. Product development (and manufacturing) matter more when the industry matures, requiring frequent variant introductions at low cost.

The PIMS studies (Buzzell and Gale 1987 [4]) looked at environment, strategy, and development variables together in one empirical study across a large number of companies in different industries. They found that market growth and market share have a key influence on profitability. In addition, product quality (performance and features as perceived by the customer) is the development performance variable that enhances profitability, while R\&D intensity (\% of sales) and product line freshness (\% 
of new products) depress profits. This result is stable across growing, mature and declining industries, with the exception that the influence of $R \& D$ intensity on profits becomes positive when industry growth is very low or negative (the industry is in decline [4, p. $277 \mathrm{ff}$.]). The PIMS study highlights the difference of the NPD performance impact between "market leaders" and "followers." For leaders, the negative influence of development intensity and product line freshness on profitability disappears, while it is significant for market followers [4, p. 280 $]^{1}$. A possible reason for this effect is that market leaders can reap larger benefits from their innovations, offsetting the NPD costs. We extend these results by investigating the influence of market share, product life cycles, and market growth on the profit impact of development performance.

The importance of industry context in explaining firm profitability has been addressed by a number of empirical studies. For example, Schmalensee (1985) [34] reported that industry membership accounted for 19.6 percent of observed variance in business unit returns. In a follow-up study, Wernerfelt and Montgomery 1988 [39] derived comparable results. Finally, Rumelt (1991) [33] found 17 percent of business unit returns explained by industry membership, only half of which was due to "structural" industry differences that are stable over time, while the other half stemmed from year-to-year industry fluctuations. Using a different methodology than the one applied in these three studies, Powell (1996) [26] used perceptual data of success and industry characteristics and also found about 20 percent of success explained by the industry context. Powell points to firm-internal factors to account for a substantial proportion of the residual variance. The present study builds on these concepts and investigates under which circumstances some proportion of this residual variance can be explained by NPD performance.

\section{HYPOTHESES}

The unit of analysis in our study is the business unit and thus follows previous studies in industrial organization and strategy $[4,33,34,39]$ as well as in the NPD performance

\footnotetext{
${ }^{1}$ In our electronics sample, we are able to replicate this result, summarized in Appendix 2.
} 
literature $[9,20]$. Our objective is to incorporate the influence of the market context into the NPD performance literature.

In a recent survey, Brown and Eisenhardt (1995) [3] observe the omission of market context variables in NPD performance research to date, which leaves two gaps in our current understanding of the link between NPD performance and business success (Figure 1).

Insert Figure 1 about here.

First, the upper question mark in Figure 1 indicates that the direct effect of the market context on business success has been insufficiently addressed. From the strategy literature, we expect that some proportion of business success variance is explained by industry membership. Consistent with Powell (1996) [26], some of the residual variance should be explained by company internal variables, one of which is development performance.

Second, Brown and Eisenhardt conjecture the existence of an indirect effect of market variables, represented by the lower question mark in Figure 1. That is, the market context influences which NPD performance variables have an impact on business success and which do not. Therefore, understanding the role of the market context is important for choosing the right dimensions of a development strategy in a particular industry. For example, introducing many new products into a market where success is driven by technical performance or low costs can be disastrous.

Figure 2 presents the model that guides the statistical analysis we conduct to address the above mentioned shortcomings. It contains both the direct and the indirect effects of the market context, as well as the link between NPD performance and business success.

Insert Figure 2 about here. 
Based on the previous research findings discussed in the literature review, we can formulate the following hypotheses about direct and indirect market environment effects:

(H1) Direct Effect) Higher market growth, higher industry profitability, longer product life cycles and a higher market share of the business unit each lead to higher profitability $[4,26,27]$.

(H2) Andirect Effect of Market Share) Companies with a small market share are more driven by the environment, i.e., the market environment variables explain a larger proportion of variance in profitability than for companies with a high market share $[22,23]$.

Formulating a hypothesis about the indirect effect of market change (growth and product life cycles) is more difficult. On the one hand, there is a widespread feeling that shortening lifecycles make product development more critical. Wheelwright and Clark $[40$, p. 5] note that "while model lives and life cycles have shrunk, firms must mount more development projects than has traditionally been the case utilizing substantially fewer resources per project." On the other hand, the results of Cusumano et al. (1992) [10] and Porter (1980) [27] suggest that the development performance dimensions are less predictive of business success in industries characterized by fast growth or fast product change. Thus, we cannot develop a theoretically sound ex-ante hypothesis concerning the influence of product life cycle and market growth on the relevant NPD performance dimensions.

\section{THE DATA}

The following variables, all of which have been identified in previous studies, were used to describe the following three dimensions of market context (explanations in brackets),

- market power (market share),

- market growth (annual industry sales growth),

- extemal stability (average product life cycle duration in the market). 
Average industry profitability is used as a control variable for industry attractiveness. Data constraints prevented us from including other economic variables such as entry barriers or inter-firm rivalry, which also influence industry attractiveness $[27,28]$.

The measurement of NPD performance follows previous work that has identified a number of performance dimensions $[15,20]$. From our data set, we were able to construct variables for the following of these dimensions:

- technical product performance (perceived performance relative to competition),

- market leadership (\% of new products being first to market),

- development intensity (development personnel per \$ million of sales),

- product line freshness (\% of sales from products introduced in the last 3 years),

- innovation rate (number of new products introduced over a life cycle, relative to industry average).

The development intensity measure could be distorted if business units were to systematically pursue short-term profits by downsizing product development ("milking" the product line). However, all the participating business units were instructed to choose a product line for their responses that was important for current and future business. Thus, we conclude that the business units are in "steady state" that is, differences in development intensity measure a different use of development resources, not disinvestment (see also [4] p. 279 f.).

We use business unit return on sales (ROS) as our dependent variable to be consistent with the studies quoted above $[33,34,39]$. Profits were defined as operating profits from the normal business, excluding extraordinary profits (or losses) and taxes. All variable definitions are consistent with [20] and shown in Figure 3.

Insert Figure 3 about here.

\section{RESEARCH METHODOLOGY}

Our analysis is based on a sample of 163 detailed questionnaires from electronics business units in the US, Japan, and Europe. During the period of 1992-1993, 101 electronics companies completed detailed questionnaires on development, operations, 
strategy and business performance as part of the Excellence in Electronics project jointly undertaken by Stanford University, the University of Augsburg, and McKinsey \& Company. Many of the world's leading companies agreed to participate in the survey, providing us with data on 12 of the 25 leading computer manufacturers and 4 of the 6 biggest TV manufacturers, to cite two industry examples. In 1994-1995, 62 electronics business units worldwide participated in a second round of the Excellence in Electronics survey.

In the first data set, measures were reported as of 1991, and in the second data set, as of 1993. Questions that were not posed in precisely the same way in both questionnaires were excluded from the analysis.

We organized the 163 completed questionnaires into 14 industry groups. These industry groups were characterized by different growth rates, industry profitability, and product life cycles. We then deleted observations for three reasons. First, 42 business units with less than $\$ 50 \mathrm{M}$ in sales were omitted, because they are often peripheral units or experimental corporate ventures. Second, 31 business units with three or more of the variables (for this study) missing in their responses were deleted. Third, scatter plots of regression residuals identified four business units as outliers in most of our regression models. After examining the characteristics of these four BUs in the original data, they were deleted from the sample (see Appendix 1). The remaining sample contained 86 business units in 12 industries with average sales of $\$ 500 \mathrm{M}$ and an average ROS of $4 \%$. Further details of the data analysis procedure are given in Appendix 1, including the correlations between the independent variables.

Insert Figure 4 about here.

Figure 4 presents the industries in the sample, with their subsample sizes, average growth rates, and product life cycles. The data contain high growth industries (relative to the median) with short and long life cycles (PCs vs. small medical systems), as well as low growth industries with short and long life cycles (TV and VCR vs. mainframes). 
Table 1 presents the results for an ordinary least square regression analysis with return on sales as the dependent variable. The other variables are as previously defined. Model la shows the expected control effect of industry profitability on the dependent variable, about 20 percent of whose variance is explained by industry profitability. These findings are consistent with $[33,34,39]$, both in terms of significance of the control variable and magnitude of the adjusted $R^{2}$ value.

Model $\mathrm{lb}$ adds the market context variables to the regression. The model now includes the control variable and the main effects of the market context. The adjusted $\mathrm{R}^{2}$ increases by five percent, with market share having a statistically significant positive influence on profitability (consistent with [4]). Market growth and product life cycles do not have a significant direct impact.

\begin{tabular}{|c|c|c|c|}
\hline Variable & Model Ia & Moxlel Ih & Model 2 \\
\hline Industry profitability & $.862^{* * *}$ & $.750^{* * *}$ & $.606^{* * *}$ \\
\hline Market share & & $.03 I^{* * *}$ & $.021^{*}$ \\
\hline Market growth & & $.0+1$ & .033 \\
\hline Product life cycle & & .001 & $.001^{*}$ \\
\hline Development intensity & & & $-.053^{* * *}$ \\
\hline Market leadership & & & .021 \\
\hline Product line freshness & & & .012 \\
\hline Innovation rate & & & -.041 \\
\hline Techn. product performance & & & $.0011^{* *}$ \\
\hline Adj. $R^{2}$ & $.186^{* * *}$ & $.236^{* * *}$ & $.343^{* * *}$ \\
\hline
\end{tabular}

Table 1: Regression for Overall Sample

In Model 2, we add our measures for development performance. The explanatory power increases to an adjusted $\mathrm{R}^{2}$ of 34 percent. In addition to the control variable and the context variable market share, two development performance variables are significant, development intensity and technical performance. All influences go in the expected directions. Hypothesis 1 is partially supported: Market share and product life cycle have a direct effect on profitability, but market growth is not significant. 


\section{SMALL VS. LARGE MARKET SHARE}

Model 2 shows a statistically significant main effect of market share in the overall regression. In addition, however, we expect market dominant firms to be subject to other success drivers than small firms. In order to investigate the influence of market share on the success drivers specified in our model, we split our sample into a high and a low market share subgroup. The split is done at the median value of market share. The two resulting subsamples are not exactly of equal size, because some observations have the same market share value and thus fall, as a group, above or below the median.

Table 2 presents the resulting regressions of the two subsamples. The first column (Model 3) applies to the high market share subsample. It provides the coefficients and significance levels of the regression with all variables (control, market context and NPD performance). The next column describes the adjusted $R^{2}$ values of three regressions. First, industry profitability alone explains 15.7 percent of profitability variance. Second, adding the three market context variables increases the $R^{2}$ to 25.9 percent. Finally, the complete model reaches an explanatory power of 53.4 percent. Note that although industry profitability alone is significant at the 1 percent level, explaining 15.7 percent of variance, this significance is taken over by other variables in the complete model.

For market dominant firms, the level of explained variance is substantially higher than in Model 2. Only half of the variance (25.9 percent) in profitability is explained by variables outside the control of product development. NPD performance explains another 27.5 percent. The most important variable is development intensity, but technical product performance also positively influences profitability.

The results for the small-market-share firms are markedly different (Model 4). Industry membership now explains almost 20 percent of firm profitability. However, adding other variables does not yield an increased (unadjusted) $R^{2}$ value. As additional variables are included without creating a better model fit, the adjusted $R^{2}$ even decreases. 
The comparison between models 3 and 4 indicates that only the big players on the market seem to be in a position to control their own success. Smaller business units are determined by environmental factors. This is in line with Hypothesis 2.

\begin{tabular}{|c|c|c|c|c|}
\hline Variable & $\begin{array}{l}\text { Model } 3 \\
\text { (high MS) }\end{array}$ & $\begin{array}{l}R^{2} \text { of } \\
\text { stubmodel }\end{array}$ & $\begin{array}{l}\text { Model } 4 \\
\text { Mow MS) }\end{array}$ & $\begin{array}{l}R^{2} \text { of } \\
\text { stubmodel }\end{array}$ \\
\hline Industry profitability & .090 & & $.912^{* * *}$ & \\
\hline & & $.157^{* * *}$ & & $.191^{* * *}$ \\
\hline Market share & .012 & & .026 & \\
\hline Market growth & .077 & & .015 & \\
\hline Product life cycle & $.00 f^{* * *}$ & $.259^{* * *}$ & -.001 & $.144^{* * *}$ \\
\hline Development intensity & $-.08 f^{* * *}$ & & -.030 & \\
\hline Market leadership & .088 & & -.074 & \\
\hline Product line freshness & .022 & & .005 & \\
\hline Innovation rate & -.007 & - & -.042 & \\
\hline Techn. product performance & $.001^{*}$ & & $.001^{*}$ & \\
\hline Total Adj. $R^{2}$ & & $.53 f^{* * *}$ & & $.109^{* * *}$ \\
\hline
\end{tabular}

Table 2: Split Sample Regression for High and Low Market Share

\section{SLOW- VS. FAST-GROWING MARKETS}

We analyze the indirect effect of market growth by dividing the 86 observations at the industry growth median, summarized in Table 3. For the high growth subsample, industry profitability explains again about 20 percent of the variance. Adding the other market context variables increases the adjusted $R^{2}$ to 28 percent. Similar to the low market share observations, adding the NPD performance measures results in a decreased adjusted $R^{2}$. None of the development performance measures is significant, indicating that success in these growing markets is controlled from outside the NPD function. We can only conjecture which variables, other than industry membership, drive success in these rapidly growing markets. This is further discussed in the outlook on further research.

In the high-growth subsample, all variance is explained through contextual variables, whereas for the low-growth subsample the opposite seems to be true. The overall fit of the model is surprisingly high, with an adjusted $R^{2}$ of 72.5 percent, of which only 23.4 
percent is explained by context variables. The key drivers of success in the regression are development intensity and technical performance. Again, market leadership is not significant, while product line freshness is. On the market context side, stability in the sense of slow growth and long life cycles positively influence firm profitability.

\begin{tabular}{|c|c|c|c|c|}
\hline Variable & $\begin{array}{l}\text { Model } 5 \\
\text { (fast growth) }\end{array}$ & $\begin{array}{l}R^{2} \text { of } \\
\text { swhmodel }\end{array}$ & $\begin{array}{l}\text { Model } 6 \\
\text { (slow growth) }\end{array}$ & $\begin{array}{l}R^{2} \text { of } \\
\text { submodel }\end{array}$ \\
\hline Industry profitability & $.870^{* *}$ & & .575 & \\
\hline & & $.205^{* * *}$ & & $.212^{* * *}$ \\
\hline Market share & $.030^{* *}$ & & .008 & \\
\hline Market growth & -.071 & & $-.543^{*}$ & \\
\hline Product life cycle & .001 & $.280^{* * *}$ & $.004^{* *}$ & $.234^{* * *}$ \\
\hline Development intensity & .025 & & $-.091^{* * *}$ & \\
\hline Market leadership & -.004 & & .059 & \\
\hline Product line freshness & .009 & & $.027^{*}$ & \\
\hline Innovation rate & .033 & & $-.093^{* *}$ & \\
\hline Techn. product performance & .001 & & $.002^{* * *}$ & \\
\hline Total Adj. $R^{2}$ & & $.200^{* * *}$ & & $.725^{* * *}$ \\
\hline$*<10 ;^{* *}<.05 ;^{* * *}<.01$ & $N=46$ & & $N=40$ & \\
\hline
\end{tabular}

Table 3: Split Sample Regression for High and Low Growth

The negative impact of innovation rate is consistent with the observation of the PIMS studies in the early 1980s [4]. Bringing out new products is costly. The benefits of bringing out more products than the average competitor seem to be outweighed by the $R \& D$ costs. In addition, those companies which continuously change their product lines may be the ones that were not successful with their old products.

\section{SHORT VS. LONG PRODUCT LIFE CYCLE}

In the final regression, we examine the indirect effect of product life cycles. The results are reported in Table 4.

For companies with fast changing products (short product life cycles) none of our variables is significant, resulting in an adjusted $\mathrm{R}^{2}$ close to zero. This negative result in Model 7 is consistent with recent observations that we need a different model to 
understand the role of new product development for fast changing companies and industries [10]. More data is needed to explore this further.

For companies with longer product life cycles, 53 percent of the variance is explained. For companies in industries with long product life cycles, market share increases profitability, and development performance also helps. Low development intensity, product line freshness and technical product performance all increase profitability.

\begin{tabular}{lllll} 
Variable & $\begin{array}{l}\text { Model 7 } \\
\text { (short life cycle) }\end{array}$ & $\begin{array}{l}R^{2} \text { of } \\
\text { suhmodel }\end{array}$ & $\begin{array}{l}\text { Model } 8 \\
\text { (long life cycle) }\end{array}$ & $\begin{array}{l}R^{2} \text { of } \\
\text { submodel }\end{array}$ \\
\hline Industry profitability & .194 & .016 & $.958^{* * *}$ & $.211^{* * *}$ \\
Market share & .018 & $.058^{* *}$ & \\
$\begin{array}{l}\text { Market growth } \\
\text { Product life cycle }\end{array}$ & .256 & & -.046 & \\
& -.001 & $.104^{*}$ & .002 & $.304^{* * *}$ \\
Development intensity & .002 & & $-.079^{* * *}$ & \\
Market leadership & .015 & & .041 & \\
Product line freshness & -.013 & & $.047^{*}$ & \\
Innovation rate & -.005 & & -.042 & \\
Techn. product performance & .001 & & .001 & $.531^{* * *}$ \\
Total Adj. $R^{2}$ & & .006 & & \\
\hline${ }^{*}<.10 ;{ }^{* *}<.05 ;{ }^{* *}<.01 ;$ & $N=40$ & & $N=46$ &
\end{tabular}

Table 4: Split Sample Regression for Short and Long Product Life Cycles

\section{DISCUSSION AND MANAGERIAL IMPLICATIONS}

Strategy research has long stressed the importance of contextual variables in explaining firm profitability. Product development literature has only recently pointed out that the currently dominant model of product development performance has been developed in, and may be mainly applicable to, mature and technologically stable industries $[3,10]$.

The present article examines the influence of the market environment on profitability, using data from 86 business units in the worldwide electronics industries. We find that in the overall sample, 23 percent of the profit variance is explained by industry 
membership. Within these 23 percent, 18 percent are contributed by industry profitability. The remaining 5 percent are explained by our market-context variables market power, market growth, and technological stability. This result is consistent with previous findings in the strategy literature $([33,34,39])$.

The second objective of this study is to investigate how the market environment influences the importance of NPD performance dimensions. Our model includes the (widely used) dimensions of market leadership, technical product performance, development intensity, innovation rate and product line freshness. We are able to show how the importance of NPD performance in explaining firm profitability substantially differs across market environments. Hypothesis 2, stating that low market share business units are driven more by their environment than large units, is supported. NPD performance explains thirty percent of profitability variance for high market share units, but none for low market share units. We also find that development performance matters more in markets of slow growth and long life cycles, where the model explains up to 70 percent of the variance.

The fact that there is no development performance profile independent of market characteristics has several managerial implications. For the large players across industries, the key to success lies in development intensity and product pefformance. Small firms can compete through superior technical performance, but the key profitability drivers are not covered by the established NPD performance dimensions.

In stable industries (slow growth or long product life cycles), development intensity and technical product performance are the key predictors of success. Introducing many new products is costly and may hurt profitability. This is consistent with previous results in $[4,6,7]$.

The substantial differences in variance explained across different market environments serve as a warning to managers not to carelessly apply results established in different markets. Our sample is restricted to the electronics industries. However, the differences even within electronics warrant caution with regard to benchmarking 
projects across industries in general, particularly when the benchmarking partners are facing different environmental conditions.

\section{THEORETICAL IMPLICATIONS AND FUTURE RESEARCH}

The theoretical contribution of this article is twofold. First, we present a contingency model of NPD performance that explicitly accounts for the impact of differing market environments. The model permits measuring the relative importance of market characteristics in explaining firm profitability and comparing it with the relative importance of NPD performance. Second, we show that the impact of NPD performance on profitability depends on the characteristics of the market environment: NPD performance is important in slowly changing industries (slow growth or long product life cycles), but explains no profitability variance in fast changing industries.

These findings suggest several directions for future research. First, our results should be validated in different industries. Second, previous research on the co-evolution of technologies and organizations $[10,35,37]$ suggests that the evolutionary state of technology represents an important variable not considered in our model. Further research on NPD performance should distinguish between pre- and post-dominant design periods.

Third, the present article focuses on a contextual approach to development performance. Recent work indicates that similar contingencies need to be considered in managing the development process. For example, Eisenhardt and Tabrizi (1995) [11] demonstrate how the NPD process differs across industries. In stable and mature industries, such as mainframes or microcomputers, Eisenhardt and Tabrizi find that concurrent engineering (overlapping of activities) reduces completion times of development projects. However, in high velocity environments such as PCs or printers, different approaches are found to be successful. Preliminary work on this topic includes $[11,17,36]$. 
Fourth, a limitation of our study is that many of our results are "negative results" in the sense that they merely point to the NPD performance model as being less applicable in rapidly changing environments. Our findings are significant enough to warrant replication with a more complete set of NPD performance variables. In addition, we are left with the challenge of identifying other business success drivers that do apply under such conditions. These drivers may be found within the traditional NPD measures, or in other functions of the organization such as marketing and distribution, or manufacturing.

In summary, future theoretical or statistical work striving to explain the connection between product development and business unit profitability must combine the effects of the industry and market environment with firm-internal variables. NPD performance measurement thus requires a more interdisciplinary approach, utilizing the insights from other management disciplines. 


\section{References}

[1] Adler, P. S. Technology strategy: A guide to the literature. Research in Technological Inmovation, Management, and Policy 4: 25 - 151 (1989).

[2] Bowen, H. K., K. B. Clark, C. A. Holloway, and S. C. Wheelwright. The Perpetual Enterprise Machine: Seven Keys to Corporate Renewal Through Successful Product and Process Development. Oxford: Oxford University Press, 1994.

[3] Brown, S. and K. M. Eisenhardt. Product development: past research, present findings, and future directions. Academy of Management Review 20: 343 - 378 (1995).

[4] Buzzell, R. D., and B. Gale. The PIMS Primciples. New York: The free Press, 1987.

[5] Clark, K. B., and T. Fujimoto. Prodhct Development Performance. Boston: Harvard Business School Press, 1991.

[6] Cooper, R. G., and E. J. Kleinschmidt. New products: What separates winners from losers. Journal of Product Imovation Management 4: 169 - 187 (1987).

[7] Cooper, R. G., and E. J. Kleinschmidt. Major new products: What distinguishes the winners in the chemical industry. Jomrnal of Product Innovation Management 10: 90 - 111 (1993).

[8] Cooper, R. G., C. J. Easingwood, S. Edgett, E. J. Kleinschmidt, and C. Storey. What distinguishes the top performing new products in financial services. Journal of Product Innovation Management 11: 281 - 299 (1994).

[9] Cooper, R. G., and E. J. Kleinschmidt. Benchmarking the Firm's Critical Success Factors in New Product Development. Journal of Product Innovation Management 12: 374 - 391 (1995).

[10] Cusumano, M.A., Y. Mylonadis, and R. S. Rosenbloom. Strategic maneuvering and mass-market dynamics: The triumph of VHS over Beta. Business History Review 66: 51 - 94 (1992).

[11] Eisenhardt, K. M., and B. N. Tabrizi. Accelerating adaptive processes: Product innovation in the global computer industry. Administrative Science Quarterly 40: $84-110(1995)$. 
[12] Firth, R. W., and V. K. Narayanan. New Product Strategies of Large, Dominant Product Manufacturing Firms: An Exploratory Analysis. Journal of Product Innovation Management 13: 334 - 347 (1996).

[13] Foster, R. N., L. H. Linden, R. L. Whiteley, and A. M. Kantrow. Improving the return on R\&D I and II. Research Management 28: 12 - 17 (Jan./ Feb. 1985) and 13 - 22 (March-April 1985).

[14] Freeman, C. The Economics of Industrial Imnovation. 2nd. ed., Cambridge, MA: MIT Press, 1986.

[15] Griffin, A., and A. L. Page. An interim report on measuring product development success and failure. Journal of Product Imovation Management 10: 291 - 308 (1993).

[16] Hair, J. F., R. E. Anderson, and R. L. Tatham. Multivariate Data Analysis. Macmillan Publishing Company, 1992.

[17] Iansiti, M. Technology Integration: Managing technological evolution in a complex environment. Research Policy 24: 521-542 (1995).

[18] Kennedy, P. A Guide to Econometrics. 3rd edition, MIT Press 1992.

[19] Lee, J. R., D. E. O'Neal, M. W. Pruett, and H. Thomas. Planning for dominance: a strategic perspective on the emergence of a dominant design. R\&D Management 25: 3 - 15 (1995).

[20] Loch, C., L. Stein, and C. Terwiesch. Development performance in the electronics Industry. Journal of Product Inmovation Management 13: 3 - 20 (1996).

[21] Loch, C. H., C. Terwiesch, and M. Niederkofler. Product development performance: Why the market context matters. Proceedings of the 3rd International Product Development Conference of the EIASM: 543 - 558 (1996).

[22] Miller, D. The genesis of configuration. Academy of Management Review 12: 686 - 701 (1987).

[23] Miller, D., and P. H. Friesen. Strategy making in context: Ten empirical archetypes. The Journal of Management Studies 14: 253 - 280 (1977).

[24] Morbey, G. K. R\&D: Its relationship with company performance. Journal of Praduct Innovation Management 5: 191 - 200 (1988).

[25] Myers, S., and D. G. Marquis. Successful industrial innovations (NSF 69-17). National Science Foundation. 
[26] Powell, T. C. How Much Does Industry Matter? An Alternative Empirical Test. Strategic Management Jommal 17: 323 - 334 (1996).

[27] Porter, M. E. Competitive Strategy. New York: The Free Press, 1980.

[28] Porter, M. E. Competitive Advantage. New York: The Free Press, 1985.

[29] Rosenbloom, R. S. Technological innovation in firms and industries: an assessment of the state of the art. in: P. Kelly and M. Kranzberg, Eds. Technological Immovation: A Critical Review of Current Knowledge. San Francisco: San Francisco Press, 1978

[30] Rosenkopf, L., and M. L. Tushman. The coevolution of technology and organization. In: Evohtionary Dynamics of ()rganizations, J. A. C. Baum and J. V. Singh (eds.). Oxford: Oxford University Press, 1994.

[31] Rothwell, R. Factors for success in industrial innovation from project SAPPHO A comparative study of success and failure in industrial innovation. Brighton, Sussex, England: S.P.R.U.

[32] Rothwell, R., C. Freeman, A. Horley, N. I. P. Jervis, A. B. Robertson, and J. Townsend. SAPPHO updated - project SAPPHO, phase II. Research Policy 3: 258 - 291 (1974).

[33] Rumelt, R. P. How much does industry matter? Strategic Management Journal 12: 167 - 185 (1991).

[34] Schmalensee, R. Do markets differ much? American Economic Review 75: 341 351 (1985).

[35] Teece, D. J. Profiting from technologcal innovation: Implications for integration, collaboration, licensing and public policy. Research Policy 15: 285 - 305 (1986)

[36] Terwiesch, C., and C. H. Loch. The role of uncertainty reduction in concurrent engineering: an analytical model and an empirical test. Working Paper 96/17/TM, INSEAD 1996.

[37] Tushman, M. L., and L. Rosenkopf. Organizational determinants of technological change. Research in Organizational Behanior 14: 311 - 347 (1992)

[38] Utterback, J. M. and F. F. Suárez. Innovation, competition and industry structure. Research Policy 22: 1 - 21 (1993).

[39] Wernerfelt, B., and C. A. Montgomery. Tobin's $q$ and the importance of focus in firm performance. American Economic Review 78 : 246 - 251 (1988). 
[40] Wheelwright, S. C., and K. B. Clark. Revolutionizing Product Development. New York: The Free Press, 1992.

[41] Zirger, B. J., and M. A. Maidique. A model of new product development: an empirical test. Management Science 36: 867 - 883 (1990). 
A business unit is defined as product-market combination. Most participating organizations are business units in this sense, having only one dominant product line. Some observations, however, had several product lines. In this case, we chose the largest for our analysis.

Of the 90 observations (after BUs below $\$ 50 \mathrm{M}$ in sales or with missing data had been eliminated), four were outliers with studentized residuals larger than three in the regressions. After checking the original data, it turned out that two of the four went through a radical shrinkage between 1989 and 1991 (sales and personnel), which pushed them into losses. The third suffered from a highly uncompetitive manufacturing cost structure leading to negative gross margins. The fourth did not fulfill our NPD "steady state" requirement, having reduced the product group reported from $100 \%$ of sales to $7 \%$ of sales between 1989 and 1991, with high profitability for the product group, but significant losses overall. Based on these these special circumstances, the four observations were deleted because extreme outliers can substantially disturb the regression analysis [16].

In the 86 observations used in the regression, there were still some data points missing. In order not to lose further observations, we replaced missing values by the average value for the variable in the corresponding industry. No data points were replaced for the dependent variable (all observations that had ROS missing were deleted), and none for industry profitability and market growth. The variable market share had the most missing data points (13). The replacement percentage was below 5 percent for all other variables, and was not concentrated on any variable, observation or industry. Since missing values were spread uniformly, deleting all observations with a missing data point would have reduced the sample size to below 50 .

Of the 86 observations, 16 were contributed by 8 business units that appeared in both data sets (1991 and 1993). They were included as separate data points, since each showed substantial differences between the two years across all variables. For example, the average absolute ROS between the two years was over 100 percent for the 8 
business units. This may be attributed to the recession that took place between 1991 and 1993, and corresponding restructuring efforts in many companies.

\begin{tabular}{|c|c|c|c|c|c|c|c|c|c|c|}
\hline Variable & mean & stdv. & 1 & 2 & 3 & 4 & 5 & 6 & 7 & 8 \\
\hline $\begin{array}{l}\text { 1. Industry } \\
\text { profitability }\end{array}$ & 0.03 & 0.07 & - & & & & & & & \\
\hline 2. Life cycle & 43.1 & 21.4 & $.50^{\circ *}$ & - & & & & & & \\
\hline 3. Market growth & 1.23 & 0.22 & $.23^{* *}$ & -.16 & - & & & & & \\
\hline 4. Market share & 0.05 & 1.20 & .04 & .05 & .00 & - & & & & \\
\hline $\begin{array}{l}\text { 5. Technical } \\
\text { performance }\end{array}$ & 44.0 & 26.4 & .16 & -.01 & .11 & .17 & - & & & \\
\hline $\begin{array}{l}\text { 6. Market } \\
\text { leadership }\end{array}$ & .50 & .31 & .11 & .01 & .09 & $.21^{* *}$ & $.29^{\cdots *}$ & - & & \\
\hline $\begin{array}{l}\text { 7. Development } \\
\text { intensity }\end{array}$ & 0.81 & 0.76 & .00 & $.26^{\circ *}$ & -.08 & -.09 & -.07 & -.05 & - & \\
\hline $\begin{array}{l}\text { 8. Product line } \\
\text { freshness }\end{array}$ & 0.70 & 0.87 & $-.24 *$ & $-.33^{\cdots}$ & .13 & -.10 & $-.18^{\circ}$ & -.02 & -.17 & - \\
\hline 9. Innovation rate & 0.00 & 0.31 & .13 & -.08 & .10 & -.10 & -.01 & .05 & $-.20^{\circ}$ & .16 \\
\hline
\end{tabular}

Two-tailed significance levels: ${ }^{*}=10 \%,{ }^{* *}=5 \%,{ }^{* *}=1 \%$

Table A-1: Correlations Between Independent Variables

Table A-1 shows the correlations between the independent variables. The two highest correlations are between product life cycles and industry profitability (50\%) and between product life cycles and product line freshness $(-33 \%)$. The low correlation coefficients indicate the absence of first order collinearity between independent variables. We calculated the condition index of the variance-covariance matrix to check for collinearity of higher order. The index of 23 is well below the recommended value $[18$, p. 183].

\section{APPENDIX 2}

Buzzell and Gale 1987 [4] find that while market share and product quality enhance profitability for all firms, market growth, $R \& D$ intensity and product line freshness are not statistically significant for market leaders. Table A-2 summarizes our corresponding split-sample regressions, which are consistent with the PIMS results. Firms with high market leadership (above the median of 0.5 ) correspond to PIMS market leaders, and firms with low market leadership to followers. 
Variable

\begin{tabular}{lll}
\hline Industry profitability & .62 & .649 \\
Market share & $.030^{*}$ & .014 \\
Market growth & .140 & -.068 \\
Product life cycle & .002 & .001 \\
& & \\
Development intensity & .080 & -.047 \\
Market leadership & .020 & $-.238^{*}$ \\
Product line freshness & .044 & .036 \\
Innovation rate & -.026 & $-.135^{*}$ \\
Techn. product performance & .001 & $.003^{* * *}$ \\
Total Adj. $R^{2}$ & $.20^{*}$ & $.23^{* *}$ \\
\hline${ }^{*}<.10 ;{ }^{* *}<.05 ;{ }^{* * *}<.01 ;$ & $N=40$ & $N=48^{\prime}$
\end{tabular}

Table A-2: Split Sample Regression for Market Leaders and Followers 
Market

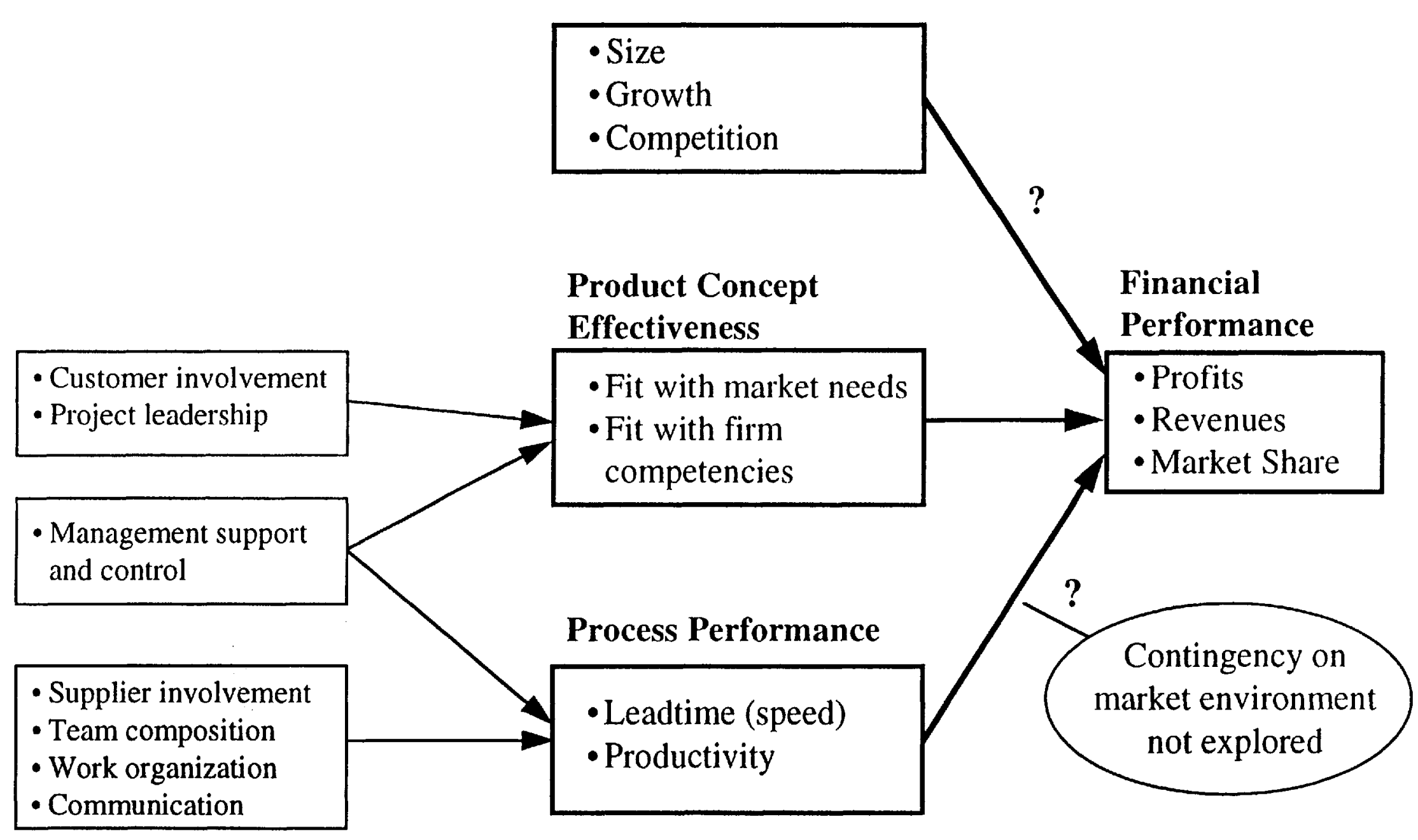

Figure 1: The Brown and Eisenhardt Metamodel 
Market Environment

- Industry Profitability

- Life Cycle

- Market Growth

- Market Share

NPD Performance

- Technical Performance

- Market Leadership

- R\&D Intensity

- Product Line Freshness

Indirect

Effect

Previous Research

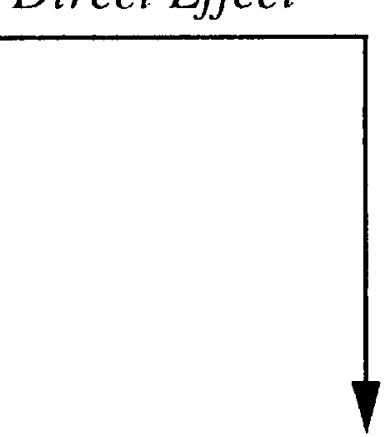

Business Unit Performance

Profitability

- Innovation Rate

\section{Figure 2: Framework for the Contingency Model}




\section{Firm Success (Dependent) Variable:}

- Profitability $=$ ROS (Return on Sales) in the last year reported before extraordinary items and taxes

\section{Development Performance Variables:}

- Market Leadership $=\%$ of significant product innovations that were first to market in the reported period (1989 1991 and 1991 - 1993, respectively)

- Technical product performance $=$ technical product performance relative to competition, as perceived by Marketing, $R \& D$, and Top Management (self reported estimation, cross checked with separate reports from R\&D, marketing, and manufacturing)

- Product line freshness $=$ Proportion of sales from products introduced the previous 3 years, as of the last year reported

- Innovation rate $=$ number of significant product line changes over the last 3 years reported, multiplied by product life cycle in years, and normalized as the relative deviation from the industry mean (the numbers used in the regression are positive or negative, with an average of zero).

- Development intensity = development personnel for the product group in question divided by product group revenues (in $\$$ million) in the last year reported.

\section{Market Context Variables:}

- Industry profitability = average ROS over the respondents in the industry in the last year reported

- Market growth, averaged over all respondents per industry = market size in the last year reported divided by market size two years ago

- Market share = worldwide volume for the product group in question, divided by worldwide volume market size, in the last year reported (domestic and value market shares were also available, and they were highly correlated with the chosen measure, with a correlation coefficient of around .9). This measure is then normalized by industry; the number used in the regression is the percent deviation, plus or minus, from the industry mean.

- Product life cycle $=$ duration of the product life cycle (in months) in the last year reported, averaged per industry.

\section{Figure 3: Definitions of Variables}




\begin{tabular}{|l|c|c|c|}
\hline \multicolumn{1}{|c|}{ Industry } & $\begin{array}{c}\text { Number of } \\
\text { Observations }\end{array}$ & $\begin{array}{c}\text { Growth } \\
\mathbf{( \% )}\end{array}$ & $\begin{array}{c}\text { Life cycle } \\
\text { (months) }\end{array}$ \\
\hline Mainframes & 4 & $-9 \%$ & 45 \\
Minicomputers & 8 & $19 \%$ & 33 \\
PCs & 12 & $36 \%$ & 18 \\
Printers & 9 & $28 \%$ & 23 \\
Large medical systems & 3 & $26 \%$ & 106 \\
Small medical systems & 3 & $53 \%$ & 72 \\
Industrial controls & 4 & $9 \%$ & 63 \\
Test and measurement systems & 16 & $14 \%$ & 61 \\
Data communication systems & 5 & $92 \%$ & 38 \\
PBX (customer premise equipment) & 5 & $7 \%$ & 59 \\
Telephone endsets & 6 & $16 \%$ & 54 \\
TV and VCR & 11 & $5 \%$ & 25 \\
\hline Total & $N^{*}=86$ & Median $=15 \%$ & Median $=35$ \\
\hline
\end{tabular}

* Sample used for statistical analysis

\section{Figure 4: Sample Composition}

